ISSN: 2162-3104 Print/ ISSN: 2166-3750 Online

Volume 8, Issue 1 (2018), pp. 251-273

(C) Journal of International Students

$\mathrm{http}: / /$ jistudents.org/

doi: 10.5281/zenodo.1134301

\title{
Creative Diversity: Promoting Interculturality in Australian Pathways to Higher Education
}

\author{
Suzanne Allen \\ University of Sydney, Australia
}

\begin{abstract}
The growth in international student enrollments in Australian pathways to higher education over the last decade is helping to broaden awareness of the presence of culturally diverse ontological perspectives. Nevertheless, tutors and students are still confronted with numerous difficulties that point to an inherent Western denial of cultural differences, of multiple identity formation, such as ethnicity, gender, class and race, and these processes of denial are stultifying the development of intercultural understanding. Methodologies that acknowledge multiplicities, however, may facilitate inclusive pedagogies and deepen interculturality. This essay addresses current problematic performances in Australian pathway contexts, both in policy implementation and pedagogical methodologies, and outlines how support for both diversity and collaboration against hegemonic practices may serve to promote interculturality.
\end{abstract}

Keywords: higher education, intercultural, international students, multiplicity, pathways

This paper is located within a broad concern for developing the quality of diversity education and interest in strategies that may initiate effective intercultural communication and understanding. In this paper, culture is perceived as the variable processes of created shared meaning, "social constructions" (Abdallah-Pretceille, 2006, p. 477). Cultural dynamics occur through multiple interrelating interpretive systems-individual, local, 
regional, national, and international. In contrast to culturalism, intercultural study recognizes paradigmatic disparity (Holliday, 2013): subject agency in re-creation (van Dijk, 2008), contextual creativity (Leeman \& Ledoux, 2003, p. 286), border permeation and hybridity (Bhabha, 2004; Spotti, 2005). Specifically, the paper examines Australia's current failings in policy and pedagogical procedures that closely affect international students within pathways to higher education. The author locates policy practices that rest upon unjust cultural assumptions and questions the nature of power of traditional policy-makers in the context of decentralized neoliberal education institutes. Continuing in the search for practices that inhibit interculturality, I turn to the limitations that lie within pedagogical practices, particularly in relation to tutors' lack of voice in the pathway context, the pervasion of Western epistemology without due space for alternative cultural perspectives, and to the narrow adoption of language styles. The theories of multiplicity and intersectionality are briefly discussed as a means of understanding diversity. From these theoretical positions, the author looks at practical strategies for acknowledging multiple identities and deconstructing the normalized of hegemonic practices.

\section{LITERATURE REVIEW}

\section{Failings in Policy and Pedagogy}

\section{Failings in Policy}

Policy development in relation to non-Australian citizens has been significantly influenced by assumed Australian national identities. The ways that Australians have defined themselves has determined how they define others. Korostelina (2007, p. 186) identifies three Australian interpretations of identity: ethnic, multicultural, and civic. After claiming the land from the indigenous Australians in the eighteenth and nineteenth centuries, the Australian state's political stance toward migrants assumed an ethnic position, promoting a British ethno-cultural identity selective of Northern and Western Europeans, British, and U.S. citizens. Given this position, cultural assimilation was to be expected. Beginning in the 1970s, a multicultural stance was promoted, whereby the cultures of ethnic groups were recognized to have the right to maintain their cultural identity. With increasing postcolonial and postmodernist discourses questioning subject identities, particularly of race, a civic conception has emerged. In this view, the individual is regarded as a national citizen with legal obligations; ethnic 
identities are irrelevant. While the Australian government attributes civic identity to nationals, however, the government stance toward international students is more in line with ethnic identification, for the international student, it is argued, does not enjoy full citizen status, and is treated as a consumer in a for-profit market (Marginson, 2012). This view is in line with those who assert that 'internationalization at home' is lacking in policy attention and underdeveloped in higher education contexts (Connell, 2013; Leask, 2015). While many changes have been implemented in Australian higher education over the last 20 years, in order to accommodate international students, it is clear that ongoing assumptions are restraining intercultural development.

Living outside their nation-state, international students' entitlements come under the 1948 United Nation's Universal Declaration of Human Rights (UN, 2016). The Declaration articulates that the Member States will adhere to a broad range of principles pertaining to universal rights, freedoms, and responsibilities, resting upon the recognition of the equality of all people: public services, legal rights, security, safety, housing, food, education, liberty in movement and opinion. However, international students are also subject to their host country's policies, which are not always concomitant with those of the Declaration. As Marginson (2012, p. 499) notes, "where national regulation reaches its limit, there the application of the universal principle also falters." This composite of policies speaks of a lack of address to the non-citizen status of international students (Marginson, 2012), which has manifested in Australia's educational policies and procedures. In pathway settings, homogeneity of race overrides acknowledgement of individual heterogeneity and agency. International students' identification through race determines their class status as neither global nor citizen, but "located in a 'gray zone' of regulation" (Marginson, 2011, p. 497), paying higher fees, and restricted in employment, residency, and political action.

\section{The ESOS Framework}

A major policy framework affecting international student education is provided in The Education Services for Overseas Students Act 2000, (ESOS Act, 2015) and associated legislation, including the National Code of Practice for Providers of Education and Training to Overseas Students 2007 (National Code) (Department of Education, Employment and Workplace Relations [DEEWR], 2007). The National Code provides the main legal structure overseeing international student services. The aim is to 
ensure nationally consistent standards of delivery by registered providers of education and training courses. The interests of overseas students are to be safeguarded in terms of "consumer protection mechanisms," "student welfare and support services," and provisions for "complaints and appeals" (DEEWR, 2007, s. A.3.1.). The focus is on provider regulations such as minimum course duration and the 20-hr week; however, the ESOS framework points to an intercultural communication void. The National Code stipulates: "cultural sensitivities must be considered to prevent offence to the students, their families or any of their representatives, for example agents" (DEEWR, 2007, s. D.6.1.). International student perspectives, nevertheless, are far from integrated into the learning environment. From the outset, international students' learning spaces are typically segregated from the mainstream student university areas. This perpetuates a pervading binary notion of cultures, typically perceived as a divide between Western and nonWestern, rather than recognition of the multiplicity of diverse differences. Through constructing binarism within the academic environment, the international student is placed in the mode of becoming "like us," still in the making, a lesser being. The plurality of cultures that international students bring is lost in the overwhelming aim to convert the non-Australian, through English, into an academic Eurocentric model.

The National Code's condition to "prevent offence" (DEEWR, 2007, s. D.6.1.) expresses the value of equity in aiming for acceptance of difference within educational institutions. The exclusion of cultures or of identities is not explicitly offensive; however, pedagogical practices that subordinate minority cultures are sustained. Cultural diversity, for example, is only superficially included in curricula, through textbook content, or assessment based on a particular issue of another country, which fails to meaningfully address or embrace different cultural perspectives. Such a task would require clear criteria and direction over the students' research. The various opinions that are expressed in a particular nation's media would need to be explored, to even begin to ascertain predominant public opinions or the government's explanations on its own stance. The National Code could better promote interculturality, for example, through local government services in "tenancy and employment rights . . . home-stay programmes, ... multiculturalism within the community . . . social networks and . . general interaction between locals and international students" (Paltridge, Mayson \& Schapper, 2012, p. 35). Instead, the legislation emphasizes "student visa integrity and consumer protection ... [and dealings for] breaches of both the ESOS Act and the National Code" (DEEWR, 2007, s. B.4.). Marginson (2012, p. 503) argued that the National Code thus appear as "a tool of 
surveillance that decisively subordinates and Others international students." Rather than challenging discriminatory practices, the ESOS framework is serving to perpetuate the identification of international students as potentially threatening entities that must be tolerated in the light of their financial worth.

\section{Tertiary Education Quality and Standards Agency}

Another significant national agency that oversees internationalization activities, a designated authority under the ESOS Act, is the Tertiary Education Quality and Standards Agency (TEQSA, 2015). TEQSA is the independent national regulator of the higher education sector, responsible for quality assurance through course and delivery practice assessments with recognition of Australian society's social and economic needs. TEQSA oversees higher education providers, which must gain TEQSA approval to deliver education to overseas students on a visa. The new Higher Education Standards Framework (2015), effective from 1 January, 2017, revises the TEQSA 2011 version in specifically addressing diversity: "Institutional policies, practices and approaches to teaching and learning are designed to accommodate student diversity" (2015, s. A2.2). Furthermore, student results are to be monitored and used to modify future admission procedures and "teaching, learning and support strategies for those subgroups" (2015, s. A2.2). The text is clear, at least, in its intent to produce more inclusive educational environments.

Kinds of strategies to implement effective change, however, are not specified. Although certain sections have been rewritten, including changes to complement the National Codes, some of the statements remain abstract and elusive. Like the 2011 Standards, the requirements stipulate that each provider "has a commitment to and support for free intellectual inquiry" (TEQSA, 2015, s. B1.1) and that "all students have opportunities to provide feedback on their educational experience and student feedback informs institutional monitoring, review and improvement activities" (TEQSA, 2015, s. A5.3). Unless evidence is requested in these areas, however, the methods for performing these practices can be superficial. The conception of what constitutes "free intellectual inquiry" (TEQSA, 2015, s. B1.1), for example, is left open to interpretation. Interculturality is dependent on conscious discussion of difference. Recognizing differing cultural interpretations, "acknowledging different frames of reference" (Department of Education, Science and Training, 2005, p. 31), is not an automatic skill. Nevertheless, education policy at the higher education level does not 
necessarily recognize and integrate international students' cultures either into pedagogical content or methodology. Policy is intrinsically orientated towards individualism and independence, whereas intercultural understanding depends upon recognition of shared humanity and interdependence. If democratic principles are worthy of safeguard, TEQSA has a responsibility to be stronger in its protective processes. To extend its current power is to become unacceptably authoritarian in the Australian democratic context. To maintain its contemporary position, however, borders on accepting its own superfluity in the midst of economic forces that are beyond its influence.

\section{Australian Skills Quality Authority}

Many providers also come under the regulation of the Australian Skills Quality Authority (ASQA), which is the ESOS agency for English language providers that do not fall within school or higher education provision. ASQA is the national regulator of the vocational education and training (VET) sector, managing provider and systemic risks to the quality of VET programs. The predominant provider risk includes registered training organizations (RTOs) incorrectly certifying a student with competencies that do not reflect his or her abilities (ASQA, 2016). Systemic risks include threats to the industry more broadly. Risk potential is investigated through the various stakeholders and market research (ASQA, 2016). ASQA authorities collaborate with state, territory, and federal funding regulatory and program agencies in their address to rectifying risk issues.

ASQA's competence in maintaining quality education across the private education provider industry has also come under scrutiny. The government's deregulation of vocational education, or contestability policy, began implementation in 2008. Contestability was driven by the theory that competition between public and private education providers for students and government subsidies would respond to employer needs and simultaneously drive quality. The regulators failed to prevent industry exploitation, however, with preference for low-cost high profit courses, engagement in full online delivery, and contraction of course lengths to "less than a quarter of the nominal duration" (Yu \& Oliver, 2015, p. 9); "if the trainer certified that someone was competent, and signed off, that was it" (Moodie, as cited in Correy, 2015). In 2015, parliamentary inquiry committees were confronted with the economic and social costs and benefits associated with for-profit diploma and advanced diploma qualifications, highlighting 
ASQA's inadequacy in maintaining quality education across the private education provider industry. Contestability thus led to a decline in quality assurance within pathway contexts (Besser \& Cronau, 2015).

As a result of the criticisms, ASQA (2016) has adopted three target strategies. In response to a 2015 Report that RTOs are enrolling students without the prerequisite skills, ASQA is escalating its attention to protecting learners from RTO unethical use of public funding. To address the issue of reduced course timeframes, ASQA is collaborating with policy makers, clarifying training needs, and ensuring adherence to stipulated prerequisites. In reply to reports of poor delivery of the Certificate IV Training and Assessment qualification, ASQA is planning to increase its regulatory inspection of questionable RTOs. Nevertheless, it is difficult not to view these intended actions as treating only the symptoms of deeper problems in the industry. There are a number of shortcomings in pedagogical methodologies currently affecting diversity education, which could be gradually dissipated through policy-making bodies that afforded a stronger humanist approach to regulatory processes.

\section{Failings in Pedagogy}

Pressure to maintain high international student intake has implicated pedagogical practices, which have in turn inhibited the development of intercultural understanding. Managerialism is the adoption of managerial methods as the means to efficient administration, with goals set for subordinates to carry out (Welch, 2013, p. 197). Organizational processes inherent to managerialism point to unresolved issues between teacher's educational values and administrative economic priorities (Marginson, 2011, p. 25). Managerialism ultimately defines individuals as commodities. Emphasis is on enrollment and graduation numbers, with a proliferation of assessments in-between. Institutions are thus characterized by a diminishing incentive to address humanist concerns or broad social issues, such as those of gender, race and class (Welch, 2013, pp. 201-202). Such contexts actually function to work against valuing student learning or to acknowledge the student through interactive discussion on multiple cultural experiences and understandings.

\section{Tutor Limitations}

As a result of managerialism, tutors are subjected to a diverse range of pressures. Centrist education not only disseminated value outcomes for 
students but also maintained principles of teacher's rights through stipulated working hours, pays, and conditions, but these fought-for working conditions in Australia have collapsed with the onset of neoliberal policies:

"An emphasis on labour market flexibility produces a growing workforce of part-time and casual and contract labour at the bottom of the organizations. Applying market discipline to the labour force has meant sustained pressure against unions. There has been an irregular but insistent roll-back of entitlements and security which the organized part of the working class had historically won." (Connell, 2013, p. 101)

The majority of pathway tutors 'must' work under contract within institutions, universities and colleges, which are managed as profit-seeking companies (Besser \& Cronau, 2015; Connell, 2013; Marginson, 2011). The widespread adoption of part-time contract work has undermined tutors' ability to influence workplace functions, which means that administrative decisions are implemented without consultation with tutors.

English language tutors have no central or collective philosophical source to reference and thus function without a strong power position. Tutors are less likely to express dissatisfaction with any aspect of work because their positions are provisional; job loss is a constant fear (Besser \& Cronau, 2015; Nakar, 2013, p. 85). In numerous pathways, semester timetables run for 10 to 14 weeks. At the end of the semester, a number of weeks are given to administrative functions, including new enrolments. Tutors are without work or pay during those weeks. They are also without the secure knowledge of whether they will receive the same amount of work as the previous semester, or less, or none at all. In such insecurity (Connell, 2013; Nakar, 2013; Ryan, 2012) compliance is a necessity. Nevertheless, there is no reward for "loyalty" or hard work, such as promotion or additional work hours, indicating that administrators are predominantly concerned with student numbers, the source of economic gain, not with academic quality.

Part-time contract positions also limit tutor interaction. Tutors who share teaching on the same unit may not necessarily see each other at all during a semester as they may be programmed on different days. Unless the institute specifies that meetings must be held and require compulsory attendance, tutors are likely to find a lack of support structures to enable sharing of professional issues. Given their part-time or casual status, tutors are neither expected nor provided the time to give social support to students (Connell, 2013; Ryan, 2012; Willmott, 1995). International students indicate 
an expectation that the teacher will provide some level of social support, as Hellsten and Prescott's participant indicates: "So, I want teacher to encourage that, and like mum or dad. . . yes, to take care of them (other international students) a lot because they are really shy and they sometimes they don't understand. . . Just to say 'OK'. . ." (as cited in Hellsten \& Prescott, 2004, p. 348). International students can thus feel heavily reliant on their own resources to overcome emotional and psychological stress that is prerequisite to a smooth pathway through academia. Amid the intense growth of managerialism, teachers have lost their rights and the regular opportunity for shared acknowledgement of their fundamental values of education (Besser \& Cronau, 2015; Connell, 2013; 2015; Ryan, 2012), a loss that has an impact on tutor-tutor and tutor-student relations.

\section{Epistemic Limitations}

A further significant hindrance to the development of interculturality is the widespread delivery of curricula that gives precedence to Western cultural unit content without adequate space for the perspectives and narratives of other cultures (Bell, 2008; Collyer \& Connell, 2016; Fahey $\&$ Kenway, 2006). There appears to be an assumption that the delivery of Western knowledge alone is legitimate, given that the international students have chosen that pathway. Emphasis on curricula demands and credit requirements (Bell, 2008; Fahey \& Kenway, 2006), developed through Western academic texts, overrides cultural questioning or investigation into alternative cultural academic expressions. Education has become a production line of acceptable Western formats. This manufactured, streamlined delivery of curricula is problematic because it is contradictory to the inherent values of academia, at least as a means of sharing social issues, with agreed willingness to listen and consider the perspectives of others. In its contradiction, the assertion of Western formats deprives value from educational experience. It not only neglects the humanitarian dimension of life but it also normalizes that neglect. The conviction that tutors' methodologies and institutional content is objective and neutral is at odds with academic recognition that pedagogical practices are inherently cultural. Intercultural diversity, including age, gender, religion, ideologies, schooling and/or profession, nation, class, ethnicity, and socio-cultural contexts, shapes knowledge definition. With acknowledgement, various cultural understandings could change dominant Western knowledge economies. 
Curricula also do not generally address recognition of prior (cultural) understandings (Chen \& Bennett, 2012), though such recognition is known to facilitate comprehension of new concepts (Kovarova, 2006; McCormick, 1995; Owens, 2011). Positivist methodologies continue to dominate pathway pedagogy. These include, as Johnson and Onwuegbuzie (2004, p. 14) identify, "emotional detachment," "rhetorical neutrality," "formal writing styles," "technical terminology," and "time- and contextfree generalizations." Instruction in these abilities, combined with continuous assessment requirements, provides little or no time to either discuss prior learning or current opinions, or to actually become involved in social issues-individually, in groups, or as a class. This is evident as Indelicato (2014, pp. 11-12) describes her experiences at the University of Sydney's Centre of English Teaching:

"We were not even asked about our previous educational experiences and study skills already accumulated [. . .] in class, we were all the same and all equally assumed to be unprepared to university life. [. . .] Our attempts were not only assessed as diverging from the model we were taught but also judged as being non-academic. For us, it was then impossible to consider this judgement as limited to our writing skills, as the very epistemologies underpinning them were also assessed as inadequate by default. As a result, most of us became disaffected from the learning context."

Indelicato's recollections of unanswered enthusiasm elucidate the misconceptions of "cultural deficit" perspectives (Ninnes, Aitchison \& Kalos, 1999) and highlight the ramifications of the apparent absence of support. Interculturality is dependent on interactive dialogue, where different opinions can be respectfully shared and discussed (Liddicoat, Papademetre, Scarino \& Kohler, 2003, p. 43). Providing students with the opportunity to elaborate from their own experience would facilitate collaborative discourses (Walker, 2005, p. 152). Discursive spaces, "communities of practice" (Dobinson, 2015, p. 365) allow for considerations on "universal sociology" (Alatas, 2011), on global identities, or opportunities to develop a cosmopolitan outlook, where "a sociality of common political engagement [is ...] either ethically or organizationally privileged over other forms of sociality" (James, 2014, p. x). Reflecting on personal experience and expressing personal views, including on unit content (Owens, 2011), can assist in the creation of such spaces. Instead, the hegemonic is made normative, academic culture unintentionally negates 
intercultural development, and students are left feeling alienated (cf. Hellsten \& Prescott, 2004; Mendan, 2012; Sawir, Marginson, Deumert, Nyland \& Ramia, 2008).

\section{Linguistic Limitations}

Another inhibition to student agency that affects interculturality lies in language use. In Australian pathway classes, students are typically only permitted to use English, not their home language. This rule is generally enforced to an unnecessary extent. For example, even when it may be useful for a student to assist another to understand a concept by using their shared home language, they are not allowed. While the intention may be educational, aiming to provide further English practice, this extreme suppression of home languages is morally questionable as an act of disempowerment. Studies on bilingual students suggest that linguistic homogenization can affect identity formation (Clyne, 2003). English privilege is critiqued through theories of literacy as social practice, in line with the Sapir-Whorf hypothesis $(1929 ; 1956)$, the notion that an individual's language determines their conceptualization. Students may be in continual mediation across national and cultural boundaries (Spotti, 2005, p. 2172) or pertain to hybrid identities, belonging to many places while not completely identifying with any in particular (Akhtar, 1999, pp. 103-104). In the classroom context, the acceptance of a principal language for communication is understandable but at the same time the appropriation of a particular language such as English needs to be sensitively and humbly utilized.

\section{RESEARCH METHOD}

\section{Theoretical Framework}

The theories of multiplicity and intersectionality provide a means to locate innovative strategies towards developing interculturality. Because tutors and international students are both subverted groups without a common voice in the Australian pathway context, new approaches are needed to promote their agency. Many authors of class, race and gender issues (cf. Connell, 2013; Hickling-Hudson, 2006; Holliday, 2013; Mohanty, 2013; Sanga \& Niroa, 2004) argue for the acknowledgment of (cultural) multiplicities (Deleuze, 1968/1994) and for the creation of coalitions against hegemonic economic and political powers. Transnational 
feminist theory (TFT), for example, "advocates for coalition-based politics that privileges multiplicity without essentializing any categories of identity" (Bhattacharya, 2013, p. 36), penetrating binarisms, while not excluding attention to subjectivity (Varga-Dobai, 2012). Consonant with Deleuze's notion of multiplicity as a substantive form, much of the literature expands upon the identities of nation, race, class and gender, such as those of place (Massey, 1994, p. 5), as well as "family, policy, discrimination, agency, violence, and motherhood" (Schmidt \& Mestry, 2014, p. 1). The aim of such approaches is to locate individual and group authoring to detect similar concerns of social and economic inequalities (Conway, 2012, p. 382; Dempsey, Parker \& Krone, 2011) and investigate methods to unify these discourses so that hegemonic practices can be overtly challenged.

Discourses of multiplicity are embedded in intersectional theory, which originated as a feminist sociological theory (Crenshaw, 1989). Intersectional theory acknowledges cultural interconnections through the multiplicity of textuality, and searches for the connections created between "axes of identity" (Crenshaw, 1989). Intersectionality is where "social identities which serve as organizing features of social relations, mutually constitute, reinforce, and naturalize one another" (Shields, 2008, p. 302). Convergent identities inform one another, impacting on the nature of experience. Intersections can be both advantageous and disadvantageous, and function individually and socially; that is, "identities instantiate social stratification" (Shields, 2008, p. 302). The theories of multiplicity and intersectionality disturb the permanent, static nature of identifications (Parent, 2013), because they announce juxtaposed differences and dialectical relationships, thereby undermining practices of homogeneity and destabilizing power positions.

\section{RESULTS}

Staff are not necessarily trained to accommodate the needs of international students or instructed on methods to internationalize their curricula content or delivery (Brewer \& Leask, 2012, p. 248). In acknowledging multiplicity and intersectionality, however, a diversity of pedagogic strategies to develop interculturality is realized by exploring identities, questioning cultural constructs, freeing artistic expressions, and unifying voices. 


\section{Exploring Identities}

Explicit discussions on the nature and function of language use in the classroom are an essential step in a range of strategies toward facilitating expression and deepening intercultural understanding. International students have been found to adopt multiple identity practices. Foregrounding these practices in the classroom could be useful for promoting writing skills. Machado-Casas (2012, p. 541) argues that in their use of social-networking platforms, migrants adopt host identities to secure physical and social survival, and home identities to secure cultural survival. Transnationals are able to communicate in their home identities while engaging in international 'cultures' that are new to them. Pedagogical acknowledgement of this skill would see students' own cultural backgrounds connected to academic literacies and identities through the construction of multiliterate and multilingual writings and identities (Skerrett, 2013, p. 323). Zhetpisbayeve, Mun, and Shelestova (2012) explore the (re)construction of cultural differences and cultural identities in intercultural settings through language selection: "Through language choice, we maintain and change ethnic group boundaries and personal relationships, and construct and define "self" and "other" within a broader political economy and historical context" (2012, p. 124). Narrative, personal stories, and the adoption of the "I" persona are methods for the expression of self, and if applied in positive writings, encourage identity affirmation (Brady et al., 2015).

\section{Questioning Cultural Constructs}

Illuminating the transitory nature of cultures and the various interpretations of them also serves to deconstruct Western hegemony, and breaks down the notion of the tutor as the owner of knowledge and the student as consumer. Explicit address to the constructed nature of Western texts, "recognition of how culture is reproduced in the classroom" (Ramsey, 2000, p. 171), requires critical focus on how the particular unit knowledge has become defined, assumed its functions, and acquired value. Tutors need to regularly acknowledge that the curricula content is challenged as a moral problematic. Questioning nationalist and polarized descriptions of cultures, as are often posited in cross-cultural research (Rizvi, 2007, p. 19), such as feminist/masculinist, collectivist/individualist, can help to foreground and promote inquiry of Western assumptions. Focus may be given to the fluid intersections of class, gender, ethnicity, age, and locality. Rejectionists of the Eurocentric can also serve as a resource of epistemic interest in the aim 
of extending current cultural knowledge and pedagogical approaches. Connell (2007) has argued that the global south produces a prolific amount of scholarship but it is oriented towards the north, leading academics to assume Eurocentric perspectives. According to Connell, four sources of thinking have predominated in the global south: Indigenous knowledge, alternative universalism (embracing, for example, Hinduism, Sikhism, Buddhism, Jainism, Islam), anti-colonial knowledge, and southern critical engagement with northern theories. Recommended strategies include questioning academic knowledge production processes and promoting southern knowledges as legitimate academic resources (Takayama, Heimans, Amazan, \& Maniam, 2016, p. 11). The integration of alternative knowledges, with preference to student knowledges, can provide for greater awareness of the constructed nature of power positions, and reinvest ownership of agency to subverted actors.

Students can regularly assume agency in their in-class learning tasks, through problem-based learning and adopting multiple learning modes. Student responsibilities can be extended through placing decisionmaking with them, such as giving them the choice of particular essay and presentation topics. Similarities and differences between submissions can be discussed, with various opinions welcomed, thus creating space to address cultural similarities and differences and to welcome diverse expressions into the shared space. Simply sharing observations and opinions of social events, such as Harmony Day and Australia Day, similarly informs students of differences in perception. Historical transitions can be briefly explained: the acceptance of the I persona in correlation with the decline of belief in an objective reality or Absolute Truth; the exclusion of visual and creative elements as an expression of the patriarchal Absolute; and the nature of knowledge as a construct, and the changing value placed on knowledges, as knowledge access and application continues to change. Western academics are closely familiar with such concepts whereas many international students may find them quite unfamiliar and strange, or have their own cultural responses to them that could provide for enriching discussion.

Students also require explicit explanations on how their cultural assertions may be misinterpreted in the Australian academic context. Rather than rejecting work such as extreme sexist assertions or "feminine" expressions (for example, love hearts and butterflies in PowerPoint presentations) as not academic, explaining why they would be questioned from a Western perspective enables students to approach their work from a more informed viewpoint. Many international students do not realize that they bring new perceptions and self-expressions, such as alternative 
interpretations of gender. Tutors need to draw students' attention to differences that they are bringing, while dispelling fear of difference and developing confidence in asserting their own ways of seeing. Such strategies are contextually relevant, for as Gargano (2012, p. 146) emphasizes, international students are consistently challenged in their efforts to make sense of the unfamiliar. The perceptions that students construct within their personal relations will be meaningful to them and have a personal value but when brought into the broader classroom context they also assume social meaning and value. It is this contextualization, or acknowledgement, that is the ultimate aim. Further activities can be drawn from the initial output: personal texts can be read to the class, shared in pairs, or collected for teacher feedback, for example. As long as the responses are predominantly accepting, the student is likely to feel encouraged to write again.

\section{Freeing Artistic Expressions}

A 2016 symposium, "Epistemologies of the South" (Collyer \& Connell), concluded that listening as a scholarly modality and "knowledge in a southern context should involve a quality of slowness that engages with the social relations at play" (Murray, 2016). One way to effectively integrate "listening" and "slowness" is to integrate arts activities. Acceptance of personal expression and creativity immediately rejects Eurocentric and neoliberal influence on education, the emphasis on market gain, on testing, on a final outcome, which depletes the social dimension of teaching, the traditional spaces for relationships of trust between teacher and student. Goldberg (2001, p. 11) states:

"Much of education involves the telling and creating of stories of our global culture. Stories are told through the spoken work, artwork, music, dance, poetry - all these languages are essential as they transmit culture both within various cultures and to people outside of the culture."

Connections between academic culture and artistic expression can be made. They depend on a willingness to do so and a creative ability to effectively utilize time (Clay, 1993). This is because the arts are not generally embraced in current academic units, even though theoretical positions support artistic methodologies.

A turn to performance, for example, is conceived as advancing theory and intercultural communication pedagogy, through uniting body and mind and thus dissipating the rupture between "the subject (self) and object 
(other) of culture" (Cooks, 2010, p. 123). Also in line with performance theory, the expansion of cultural understanding is explored through experiencing diverse cultural sites, a means of "sentient decolonization" (Garbutt, Biermann \& Offord, 2012, p. 62). Through aesthetic realization, it is argued, students can assume the agency to question education's political cultural dimensions. Additional recommendations are posited towards instigating teacher involvement in collective platforms to trigger authentic interaction between cultures (Halse \& Baumgart, 2000, p. 455). CochranSmith (2003) and Nieto (2006) promote student experience through a "cultural plunge," immersing students in culture/s far different from their own.

\section{Unifying Voices}

Emphasis is also regularly given to ways that students and staff might develop networks to strengthen their agency in the pathways contexts. Mendan (2012, p. 20) argues for student engagement in pathways to be developed through the fundamental processes of the educational institution and through social capital, "networks of relationships that allow coordination and cooperation to address social issues." Through social capital, students can access support networks that can attend to the complexities of student engagement. Emphasizing the 5- to 6-year length of the student life-cycle, Mendan posits a holistic framework to reflect the multi-dimensionality of student engagement, outlining four aspects: academic, social, emotional, and living. Institutional strategies can enhance student engagement by accommodating student engagement as "an embedded strategic capability" $(2012$, p. 20) throughout the student's entire term of enrollment.

Aronowitz (2006, p. 26) looks to the possibility of "unions of professional staff, clericals, graduate students, and maintenance employees" to promote faculty empowerment. The National Tertiary Education Union is active in advocating on contentious political issues. Letters to unions and vocalizing complaints in meetings, such as arguing to place less emphasis on assessment or to introduce alternative, more diverse forms of assessment, may eventually initiate changes that could have a strong impact on the nature of student-tutor relationships. Tutors can also ensure that students are aware of their political options, such as the National Union of Students (NUS; 2016) and the Council of International Students (CISA, 2016). Information on academic social networks that challenge the hegemonic can also be shared, such as the blog, Why Is My Curriculum White? - 
Australasia (2016). The political influence of outlets, however, depends on student knowledge of the association, awareness of his or her agency, and motivation to implement change. Pathway locations, therefore, need to not only clearly provide the means for students to initiate contact with political associations. They also need to actively support interactive communication with them, so that the political avenue is realistically experienced. Students who are becoming disconnected from class, or appear to be experiencing cultural dissonance, could benefit from such networks. Providing students with the knowledge of an association that is actively supportive can perhaps provide a stepping-stone for their release from feelings of negativity.

\section{CONCLUSION}

Intercultural education embraces a multiplicity of perspectives, of imagined 'actualities,' and through such acceptance of difference allows each person respectful and equal recognition, an imperative for students to feel that their cultural identities are acknowledged. An address to citizen rights where "each nation makes its education system into a globally responsible space", as Marginson (2011, p. 31) envisages, could facilitate approbation of diversity and the application of equity principles, but this possibility seems a long way from realization. Towards such achievement, a means of investing institutions with pluralist values is to choose to vigorously appropriate and support the practices that will most closely reflect those aims and to openly denounce practices that act against them. This will always be both an individual and social choice. Options for the decolonization of pathways, for their intercultural development, must be pursued to deconstruct the inequalities of the context. Refusing binarism (Ichiyo, 2003; Kristeva, 1982; Mohanty, 2013) through a pluralist ontology, adopting a perspective that is open to multiplicity, entails investigating the intersections of various cultural discourses; in the classroom context, multiplicity can occur in relation to ways of voicing, ways of seeing, ways of acting, and ways of knowing, and this expansion will undermine the inhibiting structures to intercultural understanding. Utilizing different language styles, providing space for the expression of personal and alternative views, integrating different learning modes, and developing student agency through maintaining clear information on power positions - these in-class methods will strengthen each student's sense of belonging to a diversified context and thereby act to promote interculturality. 


\section{REFERENCES}

Abdallah-Pretceille, M. (2006). Interculturalism as a paradigm for thinking about diversity. Intercultural Education, 17(5), 475-483. doi: 10.1080/ 14675980601065764

Akhtar, S. (1999). Immigration and identity: Turmoil, treatment, and transformation. New York: Rowman \& Littlefield.

Alatas, S. F. (2003). Academic dependency and the global division of labour in the social sciences. Current Sociology, 51(6), 599-613. doi: 10.1177/ 00113921030516003

Aronowitz, S. (2006). Should academic unions get involved in governance? Liberal Education, 92(4), 22-27.

Australian Skills Quality Authority. (2016). Report—regulatory strategy 2016-17 Version 1.0. Retrieved from http://www.asqa.gov.au/verve/_resources/ ASQA_Regulatory_Strategy_2016-17.pdf

Bell, M. (2008). Beyond the supermarket: Lost opportunities in summer study abroad for Singapore sojourners in Australia. International Journal of Asia-Pacific Studies, 4(1), 61-78.

Besser, L., \& Cronau, P. (Writers). (2015, April 20). Degrees of deception. Four Corners [Television Transcript]. Australia: Australian Broadcasting Commission. Retrieved from http://www.abc.net.au/4corners/stories/ 2015/04/20/4217741.htm

Bhabha, H. K. (2004). The location of culture. Abingdon, UK: Routledge.

Bhattacharya, K. (2013). Performing gender as "Third-World-Other" in higher education: De/colonizing transnational feminist possibilities. Creative Approaches to Research, 6(3), 30-47.

Brady, S. T., Reeves, S. L., Garcia, J., Purdie-Vaughns, V., Cook, J. E., TaborskyBarba, S., . . . Cohen, G. L. (2016). The psychology of the affirmed learner: Spontaneous self-affirmation in the face of stress. Journal of Educational Psychology, 108(3), 353-373. doi: 10.1037/edu0000091

Brewer, E., \& Leask, B. (2012). Internationalization of the curriculum. In D. K. Deardorff, H. de Wit, J. D. Heyl, \& T. Adams (Eds.), The SAGE handbook of international higher education. Thousand Oaks, CA: Sage.

Chen, R. T-H., \& Bennett, S. (2012). When Chinese learners meet constructivist pedagogy online. Higher Education, 64(5), 677-691. doi: 10.1007/s10734012-9520-9.

Clay, M. (1993). Reading recovery: A guidebook for teachers in training. Portsmouth, NH: Heinemann.

Clyne, M.G. (2003). Towards intercultural communication in Europe without linguistic homogenization. In R. de Cillia, H. J. Krumm, \& R. Wodak (Eds.), Die kostender mehrsprachigkeit [The cost of multilingualism] (pp. 39-48). Vienna: Austrian Academy of Sciences. 
Cochran-Smith, M. (2003). The multiple meanings of multicultural teacher education: A conceptual framework. Teacher Education Quarterly, 30(2), $7-26$.

Collyer, F., \& Connell, R. (2016, April 14). Australia in the global economy of knowledge: Quantitative evidence and structural analysis of Australian intellectual work in global context. Paper presented at The Epistemologies of the South symposium, Sydney, NSW.

Connell, R. (2007). Southern theory: Social Science and the global dynamics of knowledge. Sydney: Allen \& Unwin.

Connell, R. (2013). The neoliberal cascade and education: An essay on the market agenda and its consequences. Critical Studies in Education, 54(2), 99-112. doi: 10.1080/17508487.2013.776990

Conway, J. (2012). Transnational feminisms building anti-globalization solidarities. Globalizations, 9(3), 379-393. doi: 10.1080/14747731.2012.680731

Cooks, L. (2010). Revisiting the borderlands of critical intercultural communication. In T. K. Nakayama \& R. T. Halualani (Eds.), The handbook of critical intercultural communication (pp. 112-129). Hoboken, NJ: Wiley-Blackwell.

Correy, S. (Presenter). (2015, March 29). How private vocational training became an accident waiting to happen. Rear Vision [Podcast radio programme]. Sydney, NSW: ABC Radio National. Retrieved from http://www.abc.net. $\mathrm{au} / \mathrm{radionational} / \mathrm{programs} /$ rearvision/prvate-vocational-training/6340122\# transcript

Council of International Students Australia. (2016). Council of international students Australia: Representing international students in Australia. Retrieved from http://www.cisa.edu.au/

Crenshaw, K. (1989). Demarginalizing the intersection of race and sex: A black feminist critique of antidiscrimination doctrine, feminist theory and antiracist politics. The University of Chicago Legal Forum, 140, 139-167.

Deleuze, G. (1994). Difference and repetition. (P. Patton, Trans.). New York: Columbia University Press.

Dempsey, S. E., Parker, P. S., \& Krone, K. J. (2011). Navigating socio-spatial difference, constructing counter-space: Insights from transnational feminist praxis. Journal of International and Intercultural Communication, 4(3), 201-220. doi: 10.1080/17513057.2011.569973

Department of Education, Employment and Workplace Relations (DEEWR). (2007). National code of practice for providers of education and training to overseas students 2007. Retrieved from https://internationaleducation. gov.au/Regulatory-Information/Education-Services-for-Overseas-StudentsESOS-Legislative-Framework/National-Code/Pages/default.aspx

Department of Education, Science and Training. (2005). Australian Government quality teacher programme: Developing intercultural understanding-An introduction for teachers. Canberra, Australia: Author. 
Dobinson, T. (2015). Teaching and learning through the eyes of culturally and linguistically diverse postgraduates and their lecturers in Australia and Vietnam: Implications for the internationalization of education in Australian universities. Education Research and Perspectives: An International Journal, 42, 329-396.

ESOS Act, regulations, national code and legislative instruments 2000 (Cth) (Austl.). (2015). Retrieved from https://internationaleducation.gov.au/ Regulatory-Information/Education-Services-for-Overseas-Students-ESOSLegislative-Framework/ESOS-Regulations/Pages/default.aspx

Fahey, J. C., \& Kenway, J. (Eds). (2006). Globalizing the research imagination. Abingdon, UK: Routledge.

Garbutt, R., Biermann, S., \& Offord, B. (2012). Into the borderlands: Unruly pedagogy, tactile theory and the decolonizing nation. Critical Arts Projects \& Unisa Press, 26(1), 62-81. doi: 10.1080/02560046.2012.663160

Gargano, T. (2012). Grounded identities, transient lives: The emergence of international student voices in an era of cosmopolitan learning. Journal of International Students, 2(2), 144-156.

Goldberg, M. (2001). Arts and learning: An integrated approach to teaching and learning in multicultural and multilingual settings (2nd ed.). New York: Addison Wesley Longman.

Halse, C. M., \& Baumgart, N. L. (2000). Cross cultural perspectives of teachers: A study in three countries. International Journal of Intercultural Relations, 24(4), 455-475.

Hellsten, M., \& Prescott, A. (2004). Learning at university: The international student experience. International Education Journal, 5(3), 344-351. Retrieved from http://ehlt.flinders.edu.au/education/iej/main/ mainframe.htm

Hickling-Hudson, A. (2006). Cultural complexity, postcolonialism, and educational change: Challenges for comparative educators. Review of Education 52, 201-218. doi: 10.1007/s1 1159-005-5592-4

Holliday, A. (2013). The politics of ethics in diverse cultural settings: Colonising the centre stage. Compare: Journal of Comparative and International Education, 43(4), 537-554. doi: 1080/03057925.2013.797775

Ichiyo, M. (2003). Asian peace movements and empire. Inter-Asia Cultural Studies, 4(3), 460-464. doi: 10.1080/1464937032000143814

Indelicato, M. E. (2014). International students: A history of race and emotions in Australia (Unpublished doctoral dissertation). University of Sydney, Sydney, New South Wales.

James, P. (2014). Globalization and politics, Volume 4: Political philosophies of the global. Thousand Oaks, CA: Sage

Johnson, R. B., \& Onwuegbuzie, A. J. (2004). Mixed methods research: A research paradigm whose time has come. Educational Researcher, 33(7), 14-26.

Korostelina, K. V. (2007). Social identity and conflict. New York, NY: Palgrave Macmillan. 
Kovarova, A. (2006) Interactivity in educational applications using virtual reality. Retrieved from http://www2.fiit.stuba.sk/ kovarova/files/publications/ Kovarova_IITSRC2006.pdf

Kristeva, J. (1982). Powers of horror: An essay on abjection. New York: Columbia University.

Leask, B. (2015). Internationalizing the curriculum. London: Routledge.

Leeman, Y., \& Ledoux, G. (2003). Preparing teachers for intercultural education. Teaching Education, 14(3), 279-291. doi: 10.1080/1047621032000135186

Liddicoat, A. J., Papademetre, L., Scarino, A., \& Kohler, M. (2003). Report on intercultural language learning. Canberra ACT: Commonwealth of Australia. Retrieved from http://www1.curriculum.edu.au/nalsas/pdf/ intercultural.pdf

Machado-Casas, M. (2012). Pedagogies of the chameleon: Identity and strategies of survival for transnational indigenous Latino immigrants in the US south. Urban Review, 44, 534-550. doi: 10.1007/s11256-012-0206-5

Marginson, S. (2011). It's a long way down: The underlying tensions in the education export industry. Australian Universities Review, 53(2), 21-33.

Marginson, S. (2012). Including the other: Regulation of the human rights of mobile students in a nation-bound world. Higher Education, 63, 497-512. doi: 10.1007/s10734-011-9454-7

Massey, D. (2005). For space. Thousand Oaks, CA: Sage.

McCormick, S. (1995). Instructing students who have literacy problems. Mahweh, NJ: Prentice Hall.

Mendan, K. (2012). Developing a strategic capability for student engagement using social capital: A case study at a pathways college. The ACPET Journal of Private Higher Education, 1(1), 20-30.

Mohanty, C. T. (2013). Transnational feminist crossings: On neoliberalism and radical critique. Signs, 38(4), 967-991. doi: 10.1086/669576

Murray, K. (2016, April 17). The call from south symposium - slow down! [Blog Post]. Retrieved from http://www.southernperspectives.net/author/ kevinmurray

Nakar, S. (2013). Understanding VET teachers' challenges in providing quality education to international students. International Journal of Training Research, 11(1), 79-88.

National Union of Students (NUS). (2016). Retrieved from http://www.nus.org.au/

Nieto, J. (2006). The cultural plunge: Cultural immersion as a means of promoting self-awareness and cultural sensitivity among student teachers. Teacher Education Quarterly, 33(1), 75-84.

Ninnes, P., Aitchison, C., \& Kalos, S. (1999). Challenges to stereotypes of international students' prior educational experience: Undergraduate education in India. Higher Education Research \& Development, 18(3), 323-342. doi: 10.1080/0729436990180304

Owens, A. (2011). Supporting and evaluating transitional learning for international university students. Australian Universities Review, 53(1), 42-49. 
Paltridge, T., Mayson, S., \& Schapper, S. (2013). Welcome and exclusion: An analysis of The Australian newspaper's coverage of international students. Higher Education, 68, 103-116. doi 10.1007/s10734-013-9689-6

Parent, M. C., DeBlaere, C., \& Moradi, B. (2013). Approaches to research on intersectionality: Perspectives on gender, LGBT, and racial/ethnic identities. Sex Roles, 68, 639-645. doi: 10.1007/s11199-013-0283-2

Ramsey, M. (2000). Monocultural versus multicultural teaching: How to practice what we preach. Journal of Humanistic Counseling, Education and Development, 38(3), 170-183.

Rizvi, F. (2007). Beyond the East-West divide: Education and the dynamics of Australia-Asia relations. Australian Educational Researcher, 24(1), 13-26. doi: 10.1007/BF03219638

Ryan, S. (2012). Academic zombies: A failure of resistance or a means of survival? Australian Universities Review, 54(2), 3-12.

Sanga, K., \& Niroa, J. (2004). First steps and small beginnings in Vanuatu education research. In K. Sanga, J. Niroa, K. Matai, \& L. Crowl (Eds.). Rethinking Vanuatu education together. Port Vila, Vanuatu: Ministry of Education; Suva, Fiji: Institute of Pacific Studies, University of the South Pacific.

Sapir, E. (1929). The status of linguistics as a science. Language, 5(4), 207-214.

Sawir, E., Marginson, S., Deumert, A., Nyland, C., \& Ramia, G. (2008). Loneliness and international students: An Australian study. Journal of Studies in International Education, 12(2), 148-180. doi: 10.1177/1028315307299699

Schmidt, M., \& Mestry, R. (2014). South African female principalship examined through an intersectional lens. Canadian and International Education, 43(1), 1-16.

Shields, S. A. (2008). Gender: An intersectionality perspective. Sex Roles, 59, 301311. doi: 10.1007/s11199-008-9501-8

Skerrett, A. (2013). Building multiliterate and multilingual writing practices and identities. English Education, 45(4), 322-360.

Spotti, M. (2005). Bilingual identities in question: Social identity in question in a Dutch Islamic primary classroom. In J. Cohen, K. T. McAlister, K. Rolstad, \& J. MacSwan (Eds.), ISB4: Proceedings on the 4th International Symposium on Bilingualism (pp. 2165-2179). Somerville, MA: Cascadilla.

Takayama, K., Heimans, S., Amazan, R., \& Maniam, V. (2016). Doing Southern Theory: Towards alternative knowledges and knowledge practices in/for education. Postcolonial Directions in Education, 5(1), 1-25.

Tertiary Education Quality and Standards Agency (TEQSA). (2011). Higher Education Standards Framework (Threshold Standards). Canberra: Commonwealth of Australia.

Tertiary Education Quality and Standards Agency (TEQSA). (2015). Higher Education Standards Framework (Threshold Standards). Canberra: Commonwealth of Australia. 
United Nations. (2016). The universal declaration of human rights. Retrieved from http://www.ohchr.org/EN/UDHR/Documents/UDHR_Translations/eng.pdf

van Dijk, T. A. (2008). Discourse and context: A sociocognitive approach. New York: Cambridge.

Varga-Dobai, K. (2012). The relationship of researcher and participant in qualitative inquiry: From "self and other" binaries to the poststructural feminist perspective of subjectivity. The Qualitative Report, 17(93), 1-17.

Walker, T. (2005). Inter(national)-action in the classroom: Exploring a conceptual framework for investigation of spoken interaction. In B. Bartlett, F. Bryer, \& D. Roebuck (Eds.), Stimulating the 'action' as participants in participatory research, 3, (pp. 152-163). Nathan Qld: School of Cognition, Language, and Special Education: Griffith University.

Welch, A. (2013). Making education policy. In R. Connell, A. Welch, M. Vickers, D. Foley, N. Bagnall, D. Hayes, ... . C. Campbell (Eds.). Education, change and society (3rd ed.). Melbourne, Australia: OUP.

Whorf, B. (1956), Science and linguistics. In J. B. Carrol (Ed.), Language, thought and reality: Selected writings of Benjamin Lee Whorf (pp. 1-34). Cambridge, MA: Technology Press of Massachusetts Institute of Technology.

Why is my curriculum white? - Australasia. (2016). Facebook. Retrieved from https://www.facebook.com/groups/1615028005417001/

Willmott, H. (1995). Managing the academics: Commodification and control in the development of university education in the U.K. Human Relations, 48(9), 993-1027. doi: 10.1177/001872679504800902

Yu, S., \& Oliver, D. (2015). The capture of public wealth by the for-profit vet sector: A report prepared for the Australian Education Union. Sydney: Workplace Research Centre, University of Sydney Business School. Retrieved from http://www.aeufederal.org.au/Tafe/WRCAEU2015.pdf

Zhetpisbayeva, B. A., Mun, N. T., \& Shelestova, T. Y. (2012). Extralinguistic factors influencing students intercultural competence in the system of multilingual education. Education and Science Without Borders, 4(6), 124-126.

SUZANNE ALLEN is a PhD Education candidate at the University of Sydney. Her research interests include the nature of interculturality, international student issues, and pedagogy in L2 contexts. Suzanne has been teaching in international student pathways since 2009. Email: sal13002@uni.sydney.edu.au 